\title{
Ethnogenesis and Surplus Food Production: Communitas and Identity Building among Nineteenth and Early Twentieth Century Ilchamus, Lake Baringo, Kenya
}

Nik Petek ${ }^{1 a}$ and Paul J. Lane ${ }^{2 a, b}$

a) Department of Archaeology \& Ancient History, Uppsala University

b) Honorary Research Fellow, School of Geography, Archaeology \& Environmental Studies, University of the Witwatersrand

\begin{abstract}
Most archaeological discussions of surplus production tend to focus either on its role in the emergence and maintenance of social complexity (whether among hunter-gatherers, farming communities or incipient states), or on the enabling properties of surplus as a basis for technological advances and aesthetic elaboration. Here, we offer a rather different perspective on surplus as an initiator of communitas and driver of ethnogenesis following a period of intense socio-ecological stress, environmental degradation and localised demographic decline during the nineteenth century. The particular case study concerns the Maa-language speaking Ilchamus community who currently occupy areas around the southern end of Lake Baringo in the Central Rift Valley, Kenya. Drawing on a combination of new archaeological evidence, oral accounts and archival sources, the paper details the processes whereby destitute groups were drawn together into acts of surplus food production, initially of grain via the implementation of a system of irrigated agriculture and subsequently of cattle through the mobilisation of kinship and related ties. In so doing, disparate older identities were abandoned or transformed and a different, unifying ethnicity-llchamus-emerged based on a new moral economy of shared prosperity.
\end{abstract}

Key words: Kenya; Ilchamus; surplus production; communitas; ethnogenesis; irrigation agriculture

\footnotetext{
${ }^{1}$ Corresponding author, nik.petek@arkeologi.uu.se

2 paul.lane@arkeologi.uu.se
} 


\section{Introduction}

The notion of "surplus" and what is done with this has figured frequently in archaeological and anthropological discussions of social and cultural evolution (Morehart and de Lucia 2015). As recent studies highlight, the potential to produce food surplus to meet the routine nutritional needs of a social group is widely seen, from diverse theoretical positions, as an essential stimulus for different forms of trade and exchange (e.g. Ardren and Lowry 2011), the transition to food production (Testart 1982), and laying the foundations for better food security through the development of storage technologies (e.g. Wesson 1999; Manzanilla and Rothman 2016). Surplus production, moreover, has long been recognised as a driver behind the creation of social hierarchies (e.g. Stein 1994; Kenoyer 2000; Mira 2014) and the emergence of "complex societies" (e.g. Brumfiel and Earle 1987; Kirch 1994; Kim and Kusimba 2008); views that have since been expanded to include consideration of the roles of surplus labour and the creation of social inequalities (e.g. Peterson and Shelach 2012; Rosenswig 2012; Brown and Kelly 2015). Control over the production and producers of surplus, whether in the form of crops, livestock, or material goods, and the social, economic and political consequences of this have likewise been the focus of debate (Swenson and Warner 2012), as has the disposal of surplus through various forms of conspicuous consumption including feasting (e.g. Haaland 2012; Zori et al. 2013) and the construction of monumental architecture (e.g. Fisher 2014; Norman 2015). There is also an extensive body of literature on the archaeological recognition of different kinds of surplus, the modes and conditions of its production, and of its distribution (e.g. Steffian, Saltonstall, and Kopperl 2006; Van der Veen and Jones 2007; Bogaard et al. 2009; Kuijt and Finlayson 2009; Groot and Lentjes 2016) - Identifying these is nonetheless frequently challenging, as surplus is always relative and contextually defined (Morehart 2014), and consequently there are no universal material correlates for recognising its presence archaeologically.

Absent from many of these discussions, moreover, is any consideration of how, when, and why surplus might be used to build, or re-build, a sense of community identity and belonging among those who participate in its production. To stimulate such debate, we offer here an outline of one such case from Kenya during the nineteenth to early twentieth century. Here, we place more emphasis on the social values of surplus production of food, in the construction of novel identities following extreme environmental pressure that 
triggered significant re-structuring of social relations and their material expressions across a much wider area. This is not intended to diminish either the economic significance of surplus or its political ramifications, as both can be of equal or greater importance in certain contexts.

We argue, in particular, that surplus production may be mobilised by groups of loosely or entirely unrelated individuals following times of ecological crisis to create a new shared sense of community spirit and conditions wherein all members are regarded as equal participants in society. We suggest that such processes of identity construction bear some similarity to what Victor Turner (1969) described as "communitas" - a particular form of social bonding that 'emerges, if not as a spontaneous expression of sociability, at least in a cultural and normative form' during moments of social liminality (Turner 1975, 232). Turner introduced the concept primarily to explain the acute sense of solidarity, equality and togetherness that participants experience in ritual contexts while transitioning from one socially recognised state to another, such as when undergoing a rite of passage. Core features of communitas include its betwixt and between-ness, its transitory nature, and its emergence at moments when individuals step outside their normal obligations and structural roles. Turner considered this latter condition to epitomise a state of "antistructure", thereby distinguishing its particular mode of social relationship from those that typify routine, daily practice. Anti-structure may foster 'emotions to affirm an alternative (dis)order of things, which stress "generic rather than particularistic relationships"' (Blackshaw 2010, 91). Communitas is thus often regarded as having a levelling effect capable of transcending 'the limitations of class, gender, race, nationality, politics, religion or even geography' (ibid.).

Although most closely associated with a transitory phase of ritual practice, it is possible to recognise more persistent states of communitas (Turner 1969, 111-2, 125-65), which may be associated with particular forms of collective social activity, such as millenarianism and religious pilgrimage (Turner and Turner 1978). Communitas may also characterise particular moments in history when societies undergo significant transformations from one set of relatively stabilized configurations of social relations and cultural values to another. Turner $(1969,132)$ regarded these as different forms of communitas, drawing distinctions between 
'existential' spontaneous instances, more 'normative' manifestations where social control begins to become apparent, and 'ideological' forms (such as in utopian societies).

Aspects of Turner's conceptualisation of existential communitas as it relates to understanding ritual practice and religious followings can certainly be critiqued (e.g. Sallnow 1981; DeFlem 1991). Nonetheless, the concept continues to have intellectual currency, including in the fields of disaster management and humanitarian relief (Jencson 2001; Sökefeld 2012), where it is often linked to ideas of 'community resilience' (or its lack) (e.g. Grove 2014; Richardson et al. 2014). It is this cathartic dimension of communitas that we invoke here. Characterised by transformations and reformulation of previously existing social relations, we argue that the state of communitas initiated processes of ethnogenesis. Drawing on a combination of new archaeological evidence, oral histories, comparative ethnography, and agro-ecological data on crop production, specific reference is made to how shared participation in the production of food surplus, by a newly forming community of migrants with diverse origins, assisted in the formation of a new ethnic identity following widespread socio-economic and environmental 'collapse'.

\section{Immigration, economy and identity}

Understanding the formation of a novel ethnicity from various groups with separate identities requires a) knowledge of when and under what circumstances individuals and groups are willing to shift from one identity to another, and b) what circumstances and attitudes are present in the host group into which the newcomers are to be accepted. Research on attitudes towards immigrants in modern nation-states indicates that attitudes are predetermined by individuals' beliefs and that politicization and the discussion surrounding immigration shapes the acceptance/rejection of immigrants and their integration (e.g. Hainmueller, Hiscox, and Margalit 2015; Karreth, Singh, and Stojek 2015). Immigrants from societies and cultures similar to that of their host community will assimilate faster into the labour market and into the new community (Bauer, Lofstrom, and Zimmermann 2000).

Although by no means the sole driver of migration, economic growth and potential attract immigrants which, in turn, are associated with labour opportunities and wealth (Morley 2006). Since immigrants who perform better socio-economically are also willing to integrate 
more into the host community and vice-versa (Ersanilli and Koopmans 2011), the key policies of modern nation states tend to emphasize their preparation for and participation in the labour market (Joppke 2007). While East Africa in the late eighteenth century was radically different from twenty-first century Europe, similar criteria were important factors in the case of the llchamus. Their history as migrants into the Baringo region positively shaped their attitude towards newcomers to their novel community, and economic and social structures guaranteed their participation in surplus production. Moreover, their geographical and social position as an "island" of agriculture (Widgren and Sutton 2004) amongst pastoralists and hunter-gatherers gave them a unique economic standing in the regional landscape.

Historical and archaeological studies also recognize that a unique and distinct economy can be a key factor in the framing of novel group identities particularly if preceded by sociocultural disturbance. The Sanoguro in the Ecuadorian Andes, for example, only emerged following the establishment of Spanish authority over the Inca Empire (Ogburn 2008). In Kerala, India, a heavily intertwined caste system evolved into a series of endogamous communities due to the economic opportunities and (dis)advantages afforded to each by British colonial rule (Kurien 1994). Major disruptions, social or environmental, are conducive to ethnogenesis by creating environments of anti-structure and a sense of communitas among the people sharing the experience. In the process, new economic, social, and political relations are created, before eventually becoming institutionalised (Sahlins 1985). As widely documented for nineteenth century East Africa, geographic and economic divisions can become the basis for ethnic distinction (Waller 1985, 350) as, for example, among both the Marakwet (Östberg 2004, 47) and agricultural Pokot (Davies 2008) who occupy areas of the Cherangani Escarpment west of Lake Baringo. At times of community identity formation and alteration, the state and form of the economy is inseparable from ethnogenesis and it constrains or shapes the final outcome. As Hodder's (1982, 24-27) ethnoarchaeological work around Baringo highlighted, economic orientation can also be an essential part of perception of (dis)advantageous ethnicities/identities, the adoption of new ethnicities, and their material expression. 


\section{Baringo before the Ilchamus}

Located in Kenya's Rift Valley at c. 970 masl (Figure 1), Lake Baringo is bounded east and west by steep escarpments leading to well-watered highlands that comprise its water catchment. The lowlands around the lake, by contrast, are semi-arid receiving c. $600 \mathrm{~mm}$ of precipitation p.a., distributed erratically over two rainy seasons. Vegetation today is characterised by open bushland/woodland savannah dominated by Acacia spp. and increasingly by invasive forbs and shrubs (Becker et al. 2016). Much of the land is bare causing severe sheet and gully erosion, making land degradation the dominant topic of current research (e.g. Johansson and Svensson 2002; Kiage et al. 2007).

There has been limited research on the Holocene archaeology around Lake Baringo (Barthelme et al. 1983; Farrand et al. 1976; Hivernel 1979; Petek 2015), and little is known about its pre-herding, pre-farming populations. In common with other parts of the Rift Valley and adjacent highlands (Lane 2013), herding preceded farming in this area as pastoral groups reached Baringo by c. 4000 BP while pastoralism was spreading south (GiffordGonzalez 1998). Early Pastoral Neolithic (PN, c. 4800-1200 BP) sites with Elmenteitan, Narosura, and Akira wares are sparse (Hivernel 1979; Petek 2015), but suggest the presence of livestock herding communities from at least c. 3000 BP.

The scarcity of earlier PN traces contrasts with more widespread and denser concentrations of later PN Turkwel pottery (1800-950 BP) between Lakes Baringo and Bogoria (Farrand et al. 1976; Hivernel 1983; Petek 2015). Also found in Turkana and neighbouring areas of Uganda (Soper 1989), its presence in Baringo coincides with aridification from the second half of the first millennium AD (De Cort et al. 2013). In contrast, Pastoral Iron Age (c. AD 800-1850) ceramics, such as Kisima (c. AD 1450-1700) and Lanet (c. AD 900-1700) wares, are scarce. Palaeoenvironmental records indicate that the period between C. AD 1250 and 1800 was generally wetter than today, which possibly caused a decrease in C4 grasses and increase in woody and shrubby vegetation as at Lake Naivasha and in Amboseli (Driese et al. 2004; Lamb, Darbyshire, and Verschuren 2003; Rucina et al. 2010). The environment would have become less suitable for herding while enabling the expansion of tsetse flies, a vector for trypanosomiasis which is fatal to cattle, possibly causing a population decrease. A major decades-long dry spell, resulting in a significant reduction in the size of Lake Baringo is also attested around AD 1600 (Kiage and Liu 2009), which likely had a significant impact on local 
livelihoods perhaps encouraging short-term abandonment of settlements and a resurgence in hunting and gathering.

At the end of the eighteenth and start of the nineteenth century there was a further marked change to drier conditions. A sub-continental extreme drought is apparent in the palaeolimnological record across East Africa (Bessems et al. 2008), as lakes in Ethiopia, Uganda, Tanzania and across Kenya show evidence of reduced water levels or desiccation (Bessems et al. 2008; De Cort et al. 2013; Lamb, Darbyshire, and Verschuren 2003; Lamb et al. 2007; Stager and Johnson 2000; Verschuren 1999; Verschuren, Laird, and Cumming 2000; Wolff et al. 2011). Lake Baringo and the nearby Loboi swamps dried up and Lake Bogoria shallowed significantly (Ashley et al. 2004; Bessems et al. 2008; De Cort et al. 2013). The area was likely depopulated, ungulates may have migrated to other areas and there was an exceptional loss of grasses (Kiage and Liu 2009). Dubbed the "Great Catastrophe" (or its equivalent) in several regional oral histories, this catastrophe changed the socio-ethnic landscape, causing severe famine and displacement of communities, putting a strain on social structures and identities they supported (Anderson 2016). Climatic conditions ameliorated around AD 1830 and abandoned areas were re-occupied. Some communities like the East Pokot to the north and west of the lake (Bollig 2016) were reconfigured around pastoralism and livestock ownership, while elsewhere new ethnic communities emerged, such as Ilchamus. There is also compelling evidence that the age-set systems that today characterise the social organisation of a great many East African pastoralist societies, especially along the Eastern Rift Valley, were reset following the "Great Catastrophe", initiating a new beginning of time reckoning possibly using a novel system (Anderson 2016). ${ }^{1}$ In response to the social and environmental impacts of this prolonged drought, communities around Lake Baringo, on the adjacent Lorroki Plateau to the east (Simpson Jr and Waweru 2012) and further north around Lake Turkana, underwent processes of 'primary identity formation' (Bassi 2011) or 'synthetic ethnogenesis' (Ogburn 2008). Among Ilchamus this included the creation of a new age-set system and the exploitation of a new economic niche.

\section{The History of Ilchamus}

It has long been known that migrants of diverse origins contributed significantly to the formation of an Ilchamus identity (Dundas 1910; Anderson 1988; 2002; Little 1992; Spencer 
1998). However, it was only recently established that this identity began to crystallise towards the end or just after the "Great Catastrophe" (Anderson 2016). This allowed us to better correlate several events recorded in the llchamus oral history collected during our research in 2015 and by Anderson in the 1980s with our new archaeological data. In turn, by dating the sequence of events more securely, the process of Ilchamus ethnogenesis and how it arose in the aftermath of widespread and prolonged drought has become apparent for the first.

Small groups of former pastoralists drawn from different areas around Baringo, who had turned to hunting, gathering, and fishing during the "Great Catastrophe", were among the first to coalesce as climatic conditions improved. Maa-speaking Ilkeroi, commonly referred to as the "original Ilchamus", established the first settlement-Ilchamus Leabori-before being joined by Kalenjin-speaking Ilmae and Ilkapis. The latter may well have stimulated the transition to farming in the 1830 s, eventually establishing ritual control over the agricultural cycle (Anderson 1989, 86). Based on archaeological stratigraphy at the site, age-set data and information about wider historical events, a second settlement, Ilchamus Lekeper, was established in c. 1860 . Around 1840, the community initiated its first warrior age-set marking the beginnings of its ethnogenesis and new system of time-reckoning. However, the names of the first two age-sets were shared with neighbouring Maasai sections, implying a lack of a separate ethnic/community identity at this stage (Anderson 2016). Later, clans of Samburu descent would come to dominate at Leabori (Little 1985: 244). Samburu and Maa-speakers continued to be drawn to the southern end of Lake Baringo throughout the period 1840-1900, partly as a consequence of a period of prolonged inter-Maasai sectional raiding known as the Loikop wars (Anderson 1988, 2002), Rinderpest, severe droughts in 1880s (Thomson 1885; von Höhnel 1894a; Gregory 1896; Anderson 1988) and other disturbances. Groups originating in the Tugen Hills west of the lake also joined Ilchamus, and Tugen farmers and Pokot pastoralists married into the community (Anderson 1982; Little 1992, 29), as was also the case in the 1970s and 1980s (Hodder 1982, 23). Leabori and Lekeper were densely populated, fortified villages with a combined population estimated at 1500-2000 in 1887 by von Höhnel $(1892,484)$. However, the number of inhabitants probably fluctuated considerably, rising to accommodate the influx of refugees and declining as residents returned to herding (Anderson 2002, 33). Photographs taken in 
the early twentieth century, nonetheless, indicate that houses were closely packed together (Figure 2). Each village also had its own irrigation system, and oral histories ${ }^{2}$ indicate that from the 1830s, the production of an agricultural surplus became the primary focus of community life (see below), even though small herds were kept and hunting, gathering and fishing persisted, all of which helped diversify the subsistence base and may have reduced livelihood vulnerability.

From the 1830 s the irrigation systems grew considerably extending at Leabori to over $6 \mathrm{~km}^{2}$ during its peak in the 1870 s to 1880 s, stimulated partly by the demand for food after c. 1840 from passing trade caravans originating from the coast in search of ivory. As the trading frontier moved north (Håkansson 2004), Leabori became a major halt capable of resupplying caravans numbering hundreds to over a thousand individuals with grain, e.g. millet, and leafy vegetables in exchange for various imported trade goods (Beachey 1967; von Höhnel 1892, 476, 482). The importance of the irrigation system began to wane after the droughts of the 1880 s. The Ilchamus gradually transitioned to pastoralism in the early decades of the twentieth century, finally abandoning the irrigation system at Leabori in 1917 (Anderson 1988), by which time a distinct llchamus identity was well established. The question "How did a community, beginning in the 1830s and receiving continuous immigrants for 70 years, form a common identity?", thus emerges. .

Local oral histories record several prominent disputes and fissions before the Ilchamus were a well-defined ethnic entity. Interviewees confirm the lack of a common Ilchamus origin, but instead stress clan histories and identities which are still kept alive today. However, settling at either Leabori or Lekeper and commencing farming as an entry point into the community also seems to have been a common motive for many interviewees' direct ancestors. Only the origin stories of Ilkeroi, IImae, and Ilkapis clans are different. Before the "beginning of farming", likely during the time of the "Great Catastrophe", the Ilkeroi were raided frequently by the IImae and Ilkapis, who had by then settled at Leabori alongside the Ilkeroi. This is recorded as the Ilkeroi being attacked and killed during hunting, citing jealousy over their hunting skills as the reason behind these raids. Consequently, the majority of the Ilkeroi moved to Mt Elgon after cursing the land and Leabori by breaking a pot. Such accounts point to a lack of early ethnic cohesion within the settlement and the importance of clan over ethnic identities (for other regional examples of this, see, e.g. Schlee 1989). This 
schism between clans does not come to the fore in the histories of families who joined the Ilchamus subsequently. A later schism also existed between the two llchamus settlements. Each settlement had its own age-sets and initiation ceremonies, leaders, and in some cases marriages were restricted to the settlement, while a few clans were associated only with one village. Each irrigation system was also worked exclusively by the inhabitants of the settlement. Skirmishes between the two villages were common and in the late nineteenth century they agreed to separate treaties with different European powers-Lekeper signed a treaty with the German Empire in 1888 and Leabori with the British East Africa Company in 1890 (Anderson 1989; Little 1992). Affiliations and alliances, in other words, were stronger within than between settlements.

Although an idea of "Ilchamus" seems to have existed by the 1880s (Dundas 1910; PowellCotton 1904; Thomson 1885; von Höhnel 1894a), recorded disputes reveal stronger identities and affinities initially within clans and later within settlements rather than in an "Ilchamus" community as a whole. However, the disputes also reveal a common ethnic denominator growing in size and stability, even though the evidence is circumstantial. Fissures disappeared during the transition to pastoralism in the $20^{\text {th }}$ century due to the need to cooperate at a larger landscape scale, joint participation in cattle raiding against neighbouring Pokot, Tugen and Turkana, and their treatment by colonial officials as a single unified entity. Undergoing primary identity formation, the Ilchamus assimilated individuals, families, groups and clans, facilitated by economic conditions of communal production of exceptional amounts of surplus initially in grain and subsequently in livestock.

\section{The irrigation system, production, and use of surplus}

The two Ilchamus irrigation systems, which were regularly commented on by European travellers (e.g. Thomson 1885; Wakefield and Johnston 1870), ultimately encouraged a perception of Baringo among colonial officials as being one of East Africa's primary "granaries" capable of supplying a much wider region (Anderson 2002). The irrigation systems consisted of canals and channels which dissected the system into a series of smaller fields (Figure 3). Their construction depended on communal labour, as did the clearing of areas, and access to water was conditional on the contribution of labour for the construction of the irrigation system. This was both labour intensive and recurrent, as high 
siltation required consistent maintenance of the channels and frequent replacement of dams (Anderson 1989).

The social structure surrounding construction, maintenance and production within the irrigation system precluded the hijacking of the system for personal advantage as this was organised on a community level with elders making final decisions, while decisions on crop production were made at a household level, as is common across East Africa (Anderson 1989; Widgren and Håkansson 2007; Davies, Kipruto, and Moore 2014). Farming activities were further divided by gender: men dug canals, cleared fields, and fenced, and women worked the fields. Women were undoubtedly structurally disadvantaged relative to men, and may well have had more demands on their labour than would have been the case in a purely pastoralist system owing to their greater involvement in activities geared specifically toward food production, while also continuing to have responsibility for food preparation, childcare and other routine household tasks (pers. comm. Bilinda Straight). Aside from such gender imbalances, no specific clan, group of migrants, or individual household had leverage over another, making the system only minimally hierarchical, perhaps even heterarchical, and its users dependent on one another (see e.g. Davies 2009; Komakech, van Der Zaag, and van Koppen 2012). Only elders from Ilkapis and Ilmae clans had additional powers owing to their ritual authority over the farming calendar. Newcomers were given almost equal opportunities, being at slight disadvantage due to effects like water asymmetry, though forms of indebtedness were known and commonly practiced (Waller 1985; Håkansson 1998, 274).

Fields were divided like a chess board by irrigation channels into $10 \mathrm{~m}^{2}$ squares with a central, lower "basin" and a surrounding ridge c. 15-20 cm high and 40-50 cm wide on the edge, allowing a combination of both wetter and drier growing conditions (von Höhnel 1894a, 5; Anderson 1989; Little 1992, 75). Adapting their farming system to Baringo's semiarid, unpredictable climate and erratic rains (Little 1992, 24-25), the Ilchamus relied on a few key, drought-resistant crops, reducing the risk of famines and increasing the chances of surplus production. Based on oral information, Anderson (1989) identified sorghum (Sorghum bicolor spp.), bulrush or pearl millet (Pennisetum glaucum), and finger millet (Eleusine coracana) as the key cultivated species in the nineteenth and early twentieth century. Pearl millet and sorghum are drought resistant and grow successfully in areas with 
400-750 mm of annual precipitation (FAO 2016a). Finger millet, likely the dominant crop during the peak of the irrigation system, is preferred to pearl millet because of its higher yield and better storage suitability (Anderson 1989; Little 1992; Hoare 2016). Pulses were also cultivated, as suggested by the find of a single charred seed recovered from excavations undertaken in 2015 at Ilchamus Lekeper and identified as either cowpea (Vigna unguiculata) or mung bean (Vigna radiata). This is likely to have been cowpeasince it is more tolerant to drought and is commonly intercropped with sorghum, millet, and maize (Oplinger et al. 1990; Sheahan 2012). Other crops were also grown, for example maize and possibly a type of gourd (von Höhnel 1894a, 5), although as yet there is no archaeological evidence about these.

As alluded to above, reconstructing the scale of surplus production archaeologically is challenging, and this is as true for the Ilchamus case as for older agricultural landscapes, such as the late fifteenth to mid-nineteenth century irrigation complex at Engaruka, $\mathrm{N}$. Tanzania (Stump 2006). Nevertheless, in the Ilchamus case it is possible to make some informed estimates, based on a combination of remote sensing data and modern records regarding crop yields, nutritional requirements and household economies in the region. Assessment of aerial photographs taken in 1950 by the British Department of Overseas Survey, for example, shows that the irrigation system at Ilchamus Leabori was approximately 643 ha in size, divided into $10 \mathrm{~m}^{2}$ blocks abutting each other. The cultivation 'basins' were planted with millets, covering an area of c. $8.44 \mathrm{~m}^{2}$, and the ridges with sorghum and cowpea, covering c. $1.56 \mathrm{~m}^{2}$ per block (Figure 4). Calculating how much of the system was ascribed to each crop, shows that c. 542.53 ha were allocated to millet and c. 100.47 ha were likely equally divided between sorghum and cowpea, resulting in roughly 50.235 ha each. Data collated by the United Nation's Food and Agriculture Organisation (FAO)(FAO 2016b) show that the average yield in Kenya throughout the period 1961-2014 for millet and sorghum, and 1989-2014 for cowpea, was $1012.44 \mathrm{~kg} / \mathrm{ha}, 888.86 \mathrm{~kg} / \mathrm{ha}$, and $449.28 \mathrm{~kg} /$ ha respectively. Based on these figures, the system at Leabori may have been capable of yielding around $549276.36 \mathrm{~kg}$ of millet, $44652.03 \mathrm{~kg}$ of sorghum, and 22569.43 kg of cowpea per annum.

To calculate the amount of surplus produced by the system, however, an estimate of yearly consumption and the amount set aside as seeds is required. Leabori measured c. 2.69 ha in 
size with an estimated population of c. 1300 individuals (Colony and Protectorate of Kenya 1915 as cited by Little 1985, 44; see also von Höhnel 1892, 484). This gives a population density of $21 \mathrm{~m}^{2}$ per person, in line with historical photographs of the settlement and comparable to modern urban population densities. We can assess how much people consumed by subtracting the calorific value of each food source from the recommended daily adult intake of $2000 \mathrm{kcal}$ and converting the amount into grams or kilograms (European Food Information Council 2007). Based on more recent assessments of diets, it is reasonable to assume that c. $500 \mathrm{kcal}$ were consumed through wild and domestic meat, fish, milk, fruit, and wild plants such as Amaranthus spp. (mchicha in Kiswahili), water lily (nympheae spp.) and various other tubers (Little 1992, 121). Thus, the remaining $1500 \mathrm{kcal}$ would have been received from crops. Millet was the most important crop and likely represented the bulk of the calorific intake. Millet would thus have contributed $\sim 1300 \mathrm{kcal}$, sorghum $\sim 150 \mathrm{kcal}$, and cowpeas $\sim 50 \mathrm{kcal}$ to the daily adult intake. While these numbers are approximate (and ignore variations between adults and children, and between adults) they are roughly equivalent to the proportion of total yearly production of the irrigation system by each crop type. Thus an individual adult could have consumed around $340.31 \mathrm{~g}$ of millet (at $382 \mathrm{kcal} / 100 \mathrm{~g}$ - USDA Agricultural Research Service 2016a), $41.78 \mathrm{~g}$ of sorghum (at $359 \mathrm{kcal} / 100 \mathrm{~g}$ - USDA Agricultural Research Service 2016b), and $42.73 \mathrm{~g}$ of cowpeas (at $117 \mathrm{kcal} / 100 \mathrm{~g}$ - USDA Agricultural Research Service 2016c) a day. Based on these calculations, a settlement of 1300 people would consume around $442.49 \mathrm{~kg}$ of millet, 54.31 $\mathrm{kg}$ of sorghum, and $55.55 \mathrm{~kg}$ of cowpeas per day and $161477.09 \mathrm{~kg}$ of millet, $19824.61 \mathrm{~kg}$ of sorghum, and $20275.39 \mathrm{~kg}$ of cowpeas in a year. For comparison, Little (Little 1992, 118-20) assessed that an average Ilchamus homestead of 6.72 people in 1981, when pastoral foods like milk and blood comprised a greater proportion of their diet, would consume more than $800 \mathrm{~kg}$ of maize flour per year, or between 0.55 and $0.83 \mathrm{~kg}$ per day per adult. This equals $1177.43 \mathrm{kcal}$ (at $361 \mathrm{kcal} / 100 \mathrm{~g}$-USDA Agricultural Research Service 2016d) received from maize flour, which is comparable in both calorific intake and the amount consumed estimated for millet.

As for seeds, the average percentage of yield set aside across Kenya in the period from 1961-2013 for millet and sorghum and 1989-2013 for cowpeas was $2.8 \%, 2.48 \%$, and $4.75 \%$ respectively (FAO 2016b). This equals around $15379.74 \mathrm{~kg}$ of millet, $1107.37 \mathrm{~kg}$ of sorghum, 
and $1008.85 \mathrm{~kg}$ of cowpeas. Subtracting the amount consumed as food and the amount set aside as seeds from the yearly yield, the Leabori irrigation system could have produced an impressive surplus of roughly $372419.53 \mathrm{~kg}$ of millet, $23720.05 \mathrm{~kg}$ of sorghum, and 1285.19 $\mathrm{kg}$ of cowpeas, or a maximum potential total of around $397424.77 \mathrm{~kg}$ of crops, assuming that the entire complex was in productive use at the same time (which may have never been the case). This estimate represents the surplus production of only one settlement, likely during its peak in the 1870 s and early 1880s. Since no archaeological traces of the irrigation system at Lekeper have been found, it is not possible to estimate the productive potential of that system.

\section{Incentives for and effects of surplus production and use}

A yearly surplus of c. 397 tonnes is an overestimate of Lekeper's production capacity as it assumes ideal conditions for crop growth and that the yield capacity of more modern crop varieties of sorghum and millet, on which estimates and the data by the FAO are based, is equal to the varieties used by the llchamus in the nineteenth century. An unknown portion of the land is likely to have been left fallow to allow for grazing and/or cultivated with legumes such as Vigna unguiculata, which fixes nitrogen and makes it easily available to crops (Rao and Mathuva 2000) thus raising the productivity of the land. Additionally, production would have been affected by annual fluctuations in rain supply; occasional flash floods; damage from large mammals, e.g. elephants; and loss of seeds eaten by birds (von Höhnel 1894a, 5; Anderson 1989) and quite probably also locusts. The irrigation system also provided rats with a nutrient rich habitat, possibly causing the infestation noted by Thomson $(1885,264)$. Furthermore, even though the farming and irrigation systems were adapted to droughts and delayed rains, they were still not immune to them as evidenced by traveller accounts from the 1880s (Thomson 1885; Gregory 1896). Visiting in AD 1883, the explorer Joseph Thomson $(1885,312)$, for example, was unable to obtain sufficient food for his expedition, noting that the irrigation system was in decline following several years of drought, and that Ilchamus were surviving on any food they could catch and gather. Four years later, Count Teleki and von Höhnel (von Höhnel 1894b, 434) found the grain stores in both settlements empty and were unable to purchase food. Other European visitors in 1893 (Gregory 1896) and 1897 (Austin 1899) reported similar food scarcity, although by then the 
Ilchamus economy was changing once again to a focus on livestock herding. Nonetheless, the high estimate of surplus helps to explain why the Ilchamus territory was seen as prosperous and why it was written and talked about with excitement by various European visitors.

Unpredictable environmental conditions, common droughts, and participation in local and regional social and economic networks undoubtedly encouraged the llchamus to produce, or attempt to produce, significant amounts of surplus so as to weather uncertainty, and calculated estimates imply that each year Leabori alone, under ideal conditions, would have been capable of producing sufficient food for two years' subsistence and still have surplus millet to trade. An equally important motive for the production of excessive amounts of surplus, however, was the shared historical experience of the "Great Catastrophe". These, combined with a unique economic position in the Baringo region, were the initial building blocks of an Ilchamus ethnicity, a situation common to other communities undergoing ethnogenesis elsewhere in the region (e.g. Bassi 2011; Waller 1985).

Over time, the importance of clan identities, which caused initial clashes within the community, diminished. A larger group identity started forming as communal labour was employed on the irrigation system and common economic and food security goals were realised. The growing Ilchamus economy also attracted other destitute immigrant pastoralists, causing an enlargement and intensification of the irrigation. The incomers participated in cultivating and the community labour on the irrigation system, perhaps forced into it by their economic position but also attracted by opportunities and prosperous conditions creating ideal normative conditions for a shared sense of purpose. In fact, the irrigation system can be viewed as having some characteristics similar to monuments, since it had rituals and a calendar attached to it, while it also brought the community together both socially and economically ${ }^{3}$. This, combined with similar language and cultural characteristics, ensured quick integration and assimilation into the Ilchamus community (Bauer, Lofstrom, and Zimmermann 2000; Ersanilli and Koopmans 2011). As Hodder's (1982) work in Baringo established, a change of identity can be associated with economic and social advantages, which the Ilchamus could offer, including the possibility of future affluence through excessive surplus production, and the symbolic capital enjoyed by them in the regional social networks. 
Surplus grain was likely attributed different meanings throughout the $19^{\text {th }}$ century, from being a necessity due to the memory of a severe drought to a commodity and a tool of leverage in later periods of affluence. However, how and if production changes also changed the meaning of surplus remains to be clarified. As already noted, the crop surplus was used to trade with passing caravans, exchanging grain and other desirable goods such as leopard skins for beads, cloth, brass and copper wires and earrings, and occasionally bottles, small vials, and even European stoneware beer/water bottles (Figure 5). Ivory was likely exchanged only for cattle (von Höhnel 1894a, 5). The grain surplus was also used for access to and trade within the local network of pastoralists, hunter-gatherers, and agriculturalists encouraging inter-community relations and exchange/movement of people, economic specialisation and intensification, and as a security net in case of destitution (Davies 2015). However, initially, such economic advantages and relations were realised at a settlement rather than a community level. Even though material culture excavated from the two settlements shows little or no difference, Leabori and Lekeper had separate economies and the labour on the irrigation system was organised on a community level within each system, and worked exclusively by the inhabitants of each settlement (Anderson 1989). The consequence of a shared experience of community labour and the realisation of economic opportunities on a settlement level was a strong settlement identity rather than a strong ethnic Ilchamus identity, which likely explains the divide between the settlements during the latter part of the $19^{\text {th }}$ century noted by Anderson (1982) and Little (1992), and why the schism between the Ilkeroi, on the one hand, and the IImae and Ilkapis, on the other, disappeared as they inhabited Leabori. The final stages of the ethnogenesis leading to a more bounded Ilchamus identity of the kind documented ethnoarchaeologically by Hodder (1982) in the later twentieth century, only took place in the last years of the nineteenth and first years of the twentieth century, with the shift to pastoralism and when colonial involvement became palpable.

Since cattle are essential capital for farmers and herders in East Africa, surplus grain was commonly exchanged for livestock, creating a reciprocal relationship of intensification in both herding and agricultural communities. The Ilchamus, surrounded by pastoralists, actively participated in networks aimed at acquiring livestock to pay bridewealth and to maintain and enlarge herd sizes. These networks enabled them to participate in livestock 
loaning, minimising the risk of diseases and raids (Hodder 1982; Little 1992). Moreover, since destitute pastoralists immigrating into, and those identifying as, Ilchamus were keen to return to a herding lifestyle the network provided an incentive for surplus production and a means to exchange any surplus crops for livestock (Anderson 1988).

Through such processes, Ilchamus steadily acquired sufficient livestock to allow a transition to specialised pastoralism between the 1890 s and 1910s (Anderson 2002). Ilchamus were aided in their accumulation of herds by the influx of livestock obtained from their participation in punitive raids on neighbouring groups (especially Pokot) with the British (Anderson 2004). This further contributed to ethnogenesis by bringing two age-equivalent but separate Ilchamus age-sets into an identity building context (see Turton 1979 for a parallel case). By 1916, census estimates suggest that llchamus owned around 9500 cattle and 22,000 ovicaprines, reaching 18,500 cattle and 47,700 ovicaprines by 1936 when the Ilchamus numbered c. 2250 individuals (Anderson 2002, 137-141). Although only approximations, the figures nonetheless indicate a general trend toward rearing large herds of surplus livestock. This shift is reflected in the archaeological record, where only Bos and ovicaprines are present in the faunal record of Murua Olkileku, a site dating to the beginning of the twentieth century. Producing surplus livestock in semi-arid environments requires community cooperation across the landscape, and in common with trends elsewhere (Ryan et al. 2000; Waller 1990) Ilchamus settlement during the early twentieth century became more dispersed, extending across a larger landscape toward Mukutan and Kiserian/Loiminange and characterised by smaller, less aggregated settlement units dominated by a central livestock enclosure and accompanying dung mound (Petek 2015). Ultimately, growing demand for geographically extended cooperation over the landscape and growing participation in joint extra-community raids provided the basis for the final stages in Ilchamus ethnogenesis.

\section{Conclusion}

In the early nineteenth century, diverse migrant communities coalesced at the southern end of Lake Baringo, Kenya, and developed a system of irrigated agriculture as a communitybased, risk management strategy. This resulted in the production of high levels of surplus crop production. Although important for connecting inland East Africa with the global trade in elephant ivory, and commonly seen as a major cause for regional production 
intensification (Håkansson 1998, 2004), the significance of the caravan trade for the intensification of surplus production and acquisition of livestock in the llchamus case has perhaps been overstated. The potential to produce a crop surplus of c. 397 tonnes p.a. was far beyond what was needed to supply the several caravans visiting Baringo each year. Archaeological work elsewhere has noted that the nineteenth century expansion of the caravan trade neither radically transformed local food production systems, nor were the imported goods universally desirable ( Wynne-Jones 2010; Biginagwa 2012; see also von Höhnel 1894a, 5). In the llchamus case, local trade and relationship networks with neighbouring pastoral communities were much more pertinent to intensification and specialisation as Leabori and Lekeper became highly productive centres of agriculture within a landscape of less-productive ecosystems. These networks provided reliable access to livestock essential for risk reduction and constructing a dependable safety net. Wellconstructed networks are what allowed a fairly rapid transition into pastoralism for the Ilchamus, a quick build-up of herds, and access to grazing. Moreover, the surplus production of crops and later livestock was inextricably linked to the formation of an ever-larger and solidified Ilchamus ethnicity born out of a shared history of suffering following an environmental catastrophe and the sense of communitas this can engender. Elsewhere, other 'disasters' may have had a similar socially levelling effect (e.g. Kassam 2006; Straight et al. 2016), and similar kinds of ethnogenesis as described here may have even been a common coping mechanism in a region characterised by cyclical drought. Although this needs more concerted cross-disciplinary research before such claims can be treated with any certainty, as Turner $(1974,274)$ observed, 'communitas does not merge identities, it liberates them from conformity to general norms, though this is necessarily a transient condition if society is to continue to operate in an orderly fashion'. Certainly among Ilchamus, large scale surplus production and its use in local and regional trade made southern Baringo an important economic node, providing it with the reputation of a "granary" and the Ilchamus as reliable trading partners and safety net. The Ilchamus' economic and social position gave them the necessary symbolic capital to be recognised as a unique, discreet ethnic community by other ethnicities regionally and across East Africa. 


\section{Acknowledgements}

The primary archaeological fieldwork on which this paper is based forms part of Nik Petek's doctoral research at Uppsala University. This project forms part of the work of the Marie Curie Skłodowska Resilience in East African Landscapes (REAL) Innovative Training Network funded by the European Commission (FP7-PEOPLE-2013-ITN project no. 606879, awarded to Paul Lane). Additional funding for fieldwork and analyses from the National Geographic Society grant number GEFNEY 162-15; the British Institute in Eastern Africa, and the Anna Maria Lundins Travel Grant is gratefully acknowledged. The research by NP was conducted under the permit no. NACOSTI/P/14/7542/2843 provided by the National Commission for Science, Technology, and Innovation. Both authors thank Amy Bogaard, David Anderson, Kevin Walsh, Bilinda Straight, Amanda Logan and three anonymous referees for their comments on an earlier draft. We also thank David Anderson for giving us access to the transcripts of his interviews. Nik Petek would also like to thank the team Wilson Tiren, Glen Nakure, Victor Iminjili, Henry Mwangi, Benson Kones, Pauline Lekimoe, William Letasiyo, Jennifer Lentapuru, Jesinta Maitano, Tabitha Nakure, John Muasya, Onesmas, Maggie Lemaiki, Fernandos Kredgie, Joan Umazi, Sandra Nampiso, Sheilah Lemangi, John Kanyingi, Brian, and Kevin Ndiema for assisting with survey, excavations, and recording. NP would also like to thank Emily Sargeant for consistently saying "there, there" during the writing process.

\section{References}

Anderson, D.M. 1982. Herder, Settler, and Colonial Rule: A History of the Peoples of the Baringo Plains, Kenya circa 1890-1940. University of Cambridge.

- - . 1988. Cultivating Pastoralists: Ecology and Economy among the II Chamus of Baringo, 18401980. In The Ecology of Survival: Case Studies from Northeast African History, ed. D.H. Johnson and D. Anderson, 241-260. London: Lester Crook.

- - . 1989. Agriculture and Irrigation Technology at Lake Baringo in the Nineteenth Century. Azania: Archaeological Research in Africa 24: 84-97.

-- . 2002. Eroding the Commons: The Politics of Ecology in Baringo, Kenya 1890-1963. Oxford: James Currey.

- - . 2004. Massacre at Ribo Post: Expansion and Expediency on the Colonial Frontier in East 
Africa. The International Journal of African Historical Studies 37: 33-54.

- - . 2016. The Beginning of Time? Evidence for Catastrophic Drought in Baringo in the Early Nineteenth Century. Journal of Eastern African Studies 10: 45-66.

Ardren, T., and J. Lowry. 2011. The Travels of Maya Merchants in the Ninth and Tenth Centuries AD: Investigations at Xuenkal and the Greater Cupul Province, Yucatan, Mexico. World Archaeology 43: 428-443.

Ashley, G.M., J. Maitima Mworia, A.M. Muasya, R.B. Owen, S.G. Driese, V.C. Hover, R.W. Renaut, M.F. Goman, S. Mathai, and S.H. Blatt. 2004. Sedimentation and Recent History of a Freshwater Wetland in a Semi-Arid Environment: Loboi Swamp, Kenya, East Africa. Sedimentology 51: 1301-1321.

Austin, H.H. 1899. From Njemps to Marich, Save's, and Mumia's. The Geographical Journal 14: 307310.

Barthelme, J., M. LaPann, D. Werbitsky, J. Markham, R. Kellas, M. Marrero, T. French, T. Hok, R. McCartney, and S. Stocker-Edwards. 1983. Lake Baringo Archaeological Survey: A Preliminary Report. Nyame Akuma 23: 12-13.

Bassi, M. 2011. Primary Identities in the Lower Omo Valley: Migration, Cataclysm, Conflict and Amalgamation, 1750-1910. Journal of Eastern African Studies 5: 129-157.

Bauer, T., M. Lofstrom, and K.F. Zimmermann. 2000. Immigration Policy, Assimilation of Immigrants and Natives' Sentiments towards Immigrants: Evidence from 12 OECD-Countries. Bonn.

Beachey, R. 1967. The East African Ivory Trade in the Nineteenth Century. Journal of African History 9: 269-290.

Becker, M., M. Alvarez, G. Heller, P. Leparmarai, D. Maina, I. Malombe, M. Bollig, and H. Vehrs. 2016. Land-Use Changes and the Invasion Dynamics of Shrubs in Baringo. Journal of Eastern African Studies 10: 111-129.

Bessems, I., D. Verschuren, J.M. Russell, J. Hus, F. Mees, and B.F. Cumming. 2008. Palaeolimnological Evidence for Widespread Late 18th Century Drought across Equatorial East Africa. Palaeogeography, Palaeoclimatology, Palaeoecology 259: 107-120.

Biginagwa, T.J. 2012. Historical Archaeology of the Nineteenth-Century Caravan Trade in NorthEastern Tanzania: A Zooarchaeological Perspective. Azania: Archaeological Research in Africa 47: 405-406.

Blackshaw, T. 2010. Key Concepts in Community Studies, Sage Key Concepts. London: Sage. 
Bogaard, A., M. Charles, K.C. Twiss, A. Fairbairn, N. Yalman, D. Filipović, G.A. Demirergi, F. Ertuğ, N. Russell, and J. Henecke. 2009. Private Pantries and Celebrated Surplus: Storing and Sharing Food at Neolithic Çatalhöyük, Central Anatolia. Antiquity 83: 649-668.

Bollig, M. 2016. Adaptive Cycles in the Savannah: Pastoral Specialization and Diversification in Northern Kenya. Journal of Eastern African Studies 10: 21-44.

Brown, J.A., and J.E. Kelly. 2015. Surplus Labour, Ceremonial Feasting, and Social Inequality at Cahokia: A Study in Social Process. In The Politics of Production and the Strategies of Everyday Life, ed. C.T. Morehart and K. de Lucia, 221-244. Boulder, CO: University of Colorado Press.

Brumfiel, E.M., and T.K. Earle. 1987. Specialization, Exchange and Complex Societies. Cambridge: Cambridge University Press.

Colony and Protectorate of Kenya. 1915. Annual Report, Baringo District. Nairobi: Government printer.

De Cort, G., I. Bessems, E. Keppens, F. Mees, B. Cumming, and D. Verschuren. 2013. Late-Holocene and Recent Hydroclimatic Variability in the Central Kenya Rift Valley: The Sediment Record of Hypersaline Lakes Bogoria, Nakuru and Elementeita. Palaeogeography, Palaeoclimatology, Palaeoecology 388: 69-80.

Davies, M.I.J. 2008. The Irrigation System of the Pokot, Northwest Kenya. Azania: Archaeological Research in Africa 43: 50-76.

- - . 2009. Wittfogel's Dilemma: Heterarchy and Ethnographic Approaches to Irrigation Management in Eastern Africa and Mesopotamia. World Archaeology 41: 16-35.

- - . 2015. Economic Specialisation, Resource Variability, and the Origins of Intensive Agriculture in Eastern Africa. Rural Landscapes: Society, Environment, History 2: 1-18.

Davies, M.I.J., T.K. Kipruto, and H.L. Moore. 2014. Revisiting the Irrigated Agricultural Landscape of the Marakwet, Kenya: Tracing Local Technology and Knowledge over the Recent Past. Azania: Archaeological Research in Africa 49: 486-523.

DeFlem, M. 1991. Ritual, Anti-Structure, and Religion: A Discussion of Victor Turner's Processual Symbolic Analysis. Journal for the Scientific Study of Religion 30: 1-25.

Driese, S.G., G.M. Ashley, Z.-H. Li, V.C. Hover, and R.B. Owen. 2004. Possible Late Holocene Equatorial Palaeoclimate Record Based upon Soils Spanning the Medieval Warm Period and Little Ice Age, Loboi Plain, Kenya. Palaeogeography, Palaeoclimatology, Palaeoecology 213: 231-250. 
Dundas, K.R. 1910. Notes on the Tribes Inhabiting the Baringo District, East Africa Protectorate. The Journal of the Royal Anthropological Institute of Great Britain and Ireland 40: 49-72.

Earle, T.K. 1997. How Chiefs Came to Power. Stanford: Stanford University Press.

Ersanilli, E., and R. Koopmans. 2011. Do Immigrant Integration Policies Matter? A Three-Country Comparison among Turkish Immigrants. West European Politics 34: 208-234.

European Food Information Council. 2007. Making Sense of Guideline Daily Amounts.

http://www.eufic.org/article/en/nutrition/food-labelling-

claims/artid/Making_sense_of_Guideline_Daily_Amounts/. (Accessed 18 July 2016)

FAO. 2016a. Sorghum Bicolor (L.) Moench. Grassland Species Profile.

http://www.fao.org/ag/agp/agpc/doc/gbase/data/pf000319.htm. (Accessed 18 July 2016)

- - . 2016b. FAOSTAT. http://faostat3.fao.org/home/E. (Accessed 16 July 2016)

Farrand, W.R., R.W. Redding, M.H. Wolpoff, and H.T. Wright. 1976. An Archaeological Investigation on the Loboi Plain, Baringo District, Kenya. Ann Arbor: Museum of Anthropology, University of Michigan.

Fisher, K.D. 2014. The Creation and Experience of Monumentality on Protohistoric Cyprus. In Approaching Monumentality in Archaeology, ed. J.F. Osborne, 355-383. Albany, NY: SUNY Press.

Gifford-Gonzalez, D.P. 1998. Early Pastoralists in East Africa: Ecological and Social Dimensions. Journal of Anthropological Archaeology 17: 166-200.

Gregory, J.W. 1896. The Great Rift Valley: Being the Narrative of a Journey to Mount Kenya and Lake Baringo with Some Account of the Geology, Natural History, Anthropology and Future Prospects of British East Africa. London: J. Murray.

Groot, M., and D. Lentjes. 2016. Study Subsistence and Surplus Production. In Barely Surviving or More Than Enough? The Environmental Archaeology of Subsistence, Specialisation and Surplus Food Production, ed. M. Groot, D. Lentjes, and J. Zeiler, 7-27. Leiden: Sidestone Press.

Grove, K. 2014. Agency, Affect, and the Immunological Politics of Disaster Resilience. Environment and Planning D: Society and Space 32: 240-256.

Haaland, R. 2012. Changing Food Ways as Indicators of Emerging Complexity in Sudanese Nubia: From Neolithic Agropastoralists to the Meroitic Civilisation. Azania: Archaeological Research in Africa 47: 327-342. 
Hainmueller, J., M.J. Hiscox, and Y. Margalit. 2015. Do Concerns About Labor Market Competition Shape Attitudes Toward Immigration? New Evidence. Journal of International Economics 97: 193-207.

Håkansson, N.T. 1998. Rulers and Rainmakers in Precolonial South Pare, Tanzania: Exchange and Ritual Experts in Political Centralization. Ethnology 37, no. 3: 263-283.

- - . 2004. The Human Ecology of World Systems in East Africa: The Impact of the Ivory Trade. Human Ecology 32: 561-591.

Hivernel, F. 1979. An Ethnoarchaeological Study of Environmental Use in the Kenya Highlands. University College London, University of London.

- - . 1983. Excavations at Ngenyn (Baringo District, Kenya). Azania: Archaeological Research in Africa 18: 45-79.

Hoare, D.B. 2016. Eleusine Coracana (L.) Gaertn. Grassland Species Profile. http://www.fao.org/ag/agp/agpc/doc/gbase/Safricadata/eleucor.htm. (Accessed 18 July 2016) Hodder, I. 1982. Symbols in Action: Ethnoarchaeological Studies of Material Culture. Cambridge: Cambridge University Press.

Jencson, L. 2001. Disastrous Rites: Liminality and Communitas in a Flood Crisis. Anthropology and Humanism 26: 46-58.

Johansson, J., and J. Svensson. 2002. Land Degradation in the Semi-Arid Catchment of Lake Baringo, Kenya: A Minor Field Study of Physical Causes with a Socioeconomic Aspect. Göteborg.

Joppke, C. 2007. Beyond National Models: Civic Integration Policies for Immigrants in Western Europe. West European Politics 30: 1-22.

Karreth, J., S.P. Singh, and S.M. Stojek. 2015. Explaining Attitudes toward Immigration: The Role of Regional Context and Individual Predispositions. West European Politics 2382: 1-29.

Kassam, A. 2006. The people of the five "drums": Gabra ethnohistorical origins. Ethnohistory 53: 173-193.

Kenoyer, J.M. 2000. Wealth and Socioeconomic Hierarchies of the Indus Valley Civilization. In Order, Legitimacy, and Wealth in Ancient States, ed. J. Richards and M. Van Buren, 88-109. Cambridge: Cambridge University Press.

Kiage, L.M., and K. Liu. 2009. Palynological Evidence of Climate Change and Land Degradation in the Lake Baringo Area, Kenya, East Africa, since AD 1650. Palaeogeography, Palaeoclimatology, Palaeoecology 279: 60-72. 
Kiage, L.M., K. Liu, N.D. Walker, N. Lam, and O.K. Huh. 2007. Recent Land-Cover/use Change Associated with Land Degradation in the Lake Baringo Catchment, Kenya, East Africa: Evidence from Landsat TM and ETM+. International Journal of Remote Sensing 28: 4285-4309.

Kim, N.C., and C.M. Kusimba. 2008. Pathways to Social Complexity and State Formation in the Southern Zambezian Region. African Archaeological Review 25: 131-152.

Kirch, P. V. 1994. The Wet and the Dry: Irrigation and Agricultural Intensification in Polynesia. Chicago: University of Chicago Press.

Komakech, H.C., P. van Der Zaag, and B. van Koppen. 2012. The Dynamics between Water Asymmetry, Inequality and Heterogeneity Sustaining Canal Institutions in the Makanya Catchment, Tanzania. Water Policy 14: 800-820.

Kuijt, I., and B. Finlayson. 2009. Evidence for Food Storage and Predomestication Granaries 11,000 Years Ago in the Jordan Valley. Proceedings of the National Academy of Sciences 106: 1096610970.

Kurien, P. 1994. Colonialism and Ethnogenesis: A Study of Kerala, India. Theory and Society 23: 385417.

Lamb, H., I. Darbyshire, and D. Verschuren. 2003. Vegetation Response to Rainfall Variation and Human Impact in Central Kenya during the Past 1100 Years. The Holocene 13: 285-292.

Lamb, H., M.J. Leng, R.J. Telford, T. Ayenew, and M. Umer. 2007. Oxygen and Carbon Isotope Composition of Authigenic Carbonate from an Ethiopian Lake: A Climate Record of the Last 2000 Years. The Holocene 17: 517-526.

Lane, P.J. 2013. Trajectories of Pastoralism in Northern and Central Kenya: An Overview of the Archaeological and Environmental Evidence. In Pastoralism in Africa: Past, Present and Future, ed. M. Bollig, M. Schnegg, and H.-P. Wotzka, 104-144. Oxford: Berghahn.

Little, P.D. 1985. Social Differentiation and Pastoralist Sedentarization in Northern Kenya. Africa 55: 243-261.

-- - 1992. The Elusive Granary: Herder, Farmer, and State in Northern Kenya. Cambridge: Cambridge University Press.

Manzanilla, L.R., and M. Rothman. 2016. Storage in Ancient Complex Societies: Administration, Organization, and Control. Abingdon: Routledge.

Marshall, F.B., K.M. Grillo, and L. Arco. 2011. Prehistoric Pastoralists and Social Responses to Climatic Risk in East Africa. In Sustainable Lifeways: Cultural Persistence in an Ever-Changing 
Environment, ed. N.F. Miller, K.M. Moore, and K. Ryan, 39-74. Philadelphia: University of Pennsylvania Museum of Archaeology and Anthropology.

Mira, I.G. 2014. The Iron Age Landscape of Alcoi Valley, Eastern Iberia: Agricultural Intensification and Sociopolitical Dynamics. Journal of Filed Archaeology 39, no. 2: 124-133.

Morehart, C.T. 2014. The Potentiality and the Consequences of Surplus: Agricultural Production and Institutional Transformation in the Northern Basin of Mexico. Economic Anthropology 1: 154166.

Morehart, C.T., and K. de Lucia. 2015. Surplus: The Politics of Production and the Strategies of Everyday Life - An Introduction. In The Politics of Production and the Strategies of Everyday Life, ed. C. Morehart and K. de Lucia, 1-44. Boulder, CO: University of Colorado Press.

Morley, B. 2006. Causality between Economic Growth and Immigration: An ARDL Bounds Testing Approach. Economics Letters 90: 72-76.

Norman, N.L. 2015. Surplus Houses: Palace Politics in the Bight of Benin West Africa, AD 1650 1727. In The Politics of Production and the Strategies of Everyday Life, ed. C.T. Morehart and K. de Lucia, 203-220. Boulder, CO: University of Colorado Press.

Ogburn, D.E. 2008. Becoming Saraguro: Ethnogenesis in the Context of Inca and Spanish Colonialism. Ethnohistory 55: 287-319.

Oplinger, E.S., L.L. Hardman, A.R. KaminskiS, S.M. Combs, and J.D. Doll. 1990. Mungbean. Corn Agronomy. http://corn.agronomy.wisc.edu/Crops/Mungbean.aspx. (Accessed 16 July 2016)

Östberg, W. 2004. The Expansion of Marakwet Hill-Furrow Irrigation in the Kerio Valley of Kenya. In Islands of Intensive Agriculture in Eastern Africa, ed. M. Widgren and J.E.G. Sutton, 19-48. Oxford: James Currey.

Petek, N. 2015. An Archaeological Survey of the Lake Baringo Lowlands 2014: Preliminary Results. Nyame Akuma 83: 100-111.

Peterson, C.E., and G. Shelach. 2012. Jiangzhai: Social and Economic Organization of a Middle Neolithic Chinese Village. Journal of Anthropological Archaeology 31: 265-301.

Powell-Cotton, P.H.G. 1904. In Unknown Africa: A Narrative of Twenty Months' Travel and Sport in Unknown Lands and among New Tribes. London: Hurst and Blackett, Limited.

Rao, M.R., and M.N. Mathuva. 2000. Legumes for Improving Maize Yields and Income in Semi-Arid Kenya. Agriculture, Ecosystems and Environment 78: 123-137.

Richardson, B.K., L.K. Siebeneck, S. Shaunfield, and E. Kaszynski. 2014. From “No Man's Land” to a 
"Stronger Community": Communitas as a Theoretical Framework for Successful Disaster Recovery. International Journal of Mass Emergencies \& Disasters 32: 194-219.

Rosenswig, R.M. 2012. Materialism, Mode of Production, and a Millennium of Change in Southern Mexico. Journal of Archaeological Method and Theory 19: 1-48.

Rucina, S.M., V.M. Muiruri, L. Downton, and R. Marchant. 2010. Late-Holocene Savanna Dynamics in the Amboseli Basin, Kenya. The Holocene 20: 667-677.

Ryan, K., Karega-Munene, S. Kahinju, and P.N. Kunoni. 2000. Ethnographic Perspectives on Cattle Management in Semi-Arid Environments: A Case Study from Maasailand. In The Origins and Development of African Livestock: Archaeology, Genetics, Linguistics, and Ethnography, ed. R. Blench and K.C. MacDonald, 467-477. London: UCL Press.

Sahlins, M.D. 1985. Islands of History. Chicago: University of Chicago Press.

Sallnow, M.J. 1981. Communitas Reconsidered: The Sociology of Andean Pilgrimage. Man 16: 163182.

Schlee, G. 1989. Identities on the Move: Clanship and Pastoralism in Northern Kenya. Manchester: Manchester University Press

Sheahan, C.M. 2012. Plant Guide for Cowpea (Vigna Unguiculata). USDA-Natural Resources Conservation Service. (Cape May, NJ: USDA-Natural Resources Conservation Service, Cape May Plant Materials Center).

Simpson Jr, G.L., and P. Waweru. 2012. Becoming Samburu: The Ethnogenesis of a Pastoral People in Nineteenth-Century Northern Kenya. Journal of the Middle East and Africa 3: 175-197.

Soper, R. 1989. History of Pottery in Kenya. In Kenyan Pots and Potters, ed. J. Barbour and S. Wandibba, 6-26. Nairobi: Oxford University Press.

Sökefeld, M. 2012. Exploring the Link between Natural Disasters and Politics: Case Studies of Pakistan and Peru. Journal of International and Pakistan Studies 5-6: 1-32.

Spencer, P. 1998. The Pastoral Continuum: The Marginalisation of Tradition in East Africa. Oxford: Oxford University Press.

Stager, J.C., and T.C. Johnson. 2000. A 12,400 14C Yr Offshore Diatom Record from East Central Lake Victoria, East Africa. Journal of Paleolimnology 23: 373-383.

Steffian, A.F., P.G. Saltonstall, and R.E. Kopperl. 2006. Expanding the Kachemak: Surplus Production and the Development of Multi-Season Storage in Alaska's Kodiak Archipelago. Arctic Anthropology 43: 93-129. 
Stein, G. 1994. Economy, Ritual, and Power in 'Ubaid Mesopotamia. In Chiefdoms and Early States in the Near East: The Organizational Dynamics of Complexity, ed. G. Stein and M.S. Rothman, 3546. Prehistory Press: Monographs in World Archaeology 18.

Straight, B., Lane, P.J., Hilton, C. and Letua, M. 2016. 'Dust People': Samburu perspectives on disaster, identity, and landscape. Journal of East African Studies 10: 168-188.

Stump, D. 2006. The Development and Expansion of the Field and Irrigation Systems at Engaruka, Tanzania. Azania: Archaeological Research in Africa 41: 69-94.

Swenson, E.R., and J.P. Warner. 2012. Crucibles of Power: Forging Copper and Forging Subjects at the Moche Ceremonial Center of Huaca Colorada, Peru. Journal of Anthropological Archaeology 31: 314-333.

Testart, A. 1982. The Significance of Food Storage among Hunter-Gatherers. Current Anthropology 23: 523-537.

Thomson, J. 1885. Through Masai Land: A Journey of Exploration among the Snowclad Volcanic Mountains and Strange Tribes of Eastern Equatorial Africa. 1st Editio. London: Sampson, Low, Marston, Searle, \& Rivington.

Turner, V.W. 1969. The Ritual Process: Structure and Anti-Structure. Ithaca, N. Y.: Cornell University Press.

-- . 1974. Dramas, Fields, and Metaphors: Symbolic Action in Human Society. Ithaca, N. Y.: Cornell University Press.

- - . 1975. Revelation and Divination in Ndembu Ritual. Ithaca, N. Y.: Cornell University Press.

Turner, V.W., and E. Turner. 1978. Image and Pilgrimage in Christian Culture. New York: Columbia University Press.

Turton, D. 1979. War, Peace, and Mursi Identity. Senri Ethnological Studies 3: 179-210.

USDA Agricultural Research Service. 2016a. Basic Report: 20647, Millet Flour. National Nutrient Database for Standard Reference Release 28.

https://ndb.nal.usda.gov/ndb/foods/show/6642?manu=\&fgcd. (Accessed 18 July 2016)

-- - 2016b. Basic Report: 20648, Sorghum Flour, Whole-Grain. National Nutrient Database for Standard Reference Release 28. https://ndb.nal.usda.gov/ndb/foods/show/6643?manu=\&fgcd. (Accessed 18 July 2016)

- - 2016c. Basic Report: 16061, Cowpeas, Catjang, Mature Seeds, Cooked, Boiled, without Salt. National Nutrient Database for Standard Reference Release 28. 
https://ndb.nal.usda.gov/ndb/foods/show/4800?manu=\&fgcd. (Accessed 18 July 2016)

- - 2016d. Basic Report: 20316, Corn Flour, Whole-Grain, White. National Nutrient Database for Standard Reference Release 28. https://ndb.nal.usda.gov/ndb/foods/show/6597?manu=\&fgcd. (Accessed 18 July 2016)

Van der Veen, M., and G. Jones. 2007. The Production and Consumption of Cereals: A Question of Scale. In The Later Iron Age in Britain and Beyond, ed. C. Haselgrove and T. Moore, 419-429. Oxford: Oxbow Books.

Verschuren, D. 1999. Sedimentation Controls on the Preservation and Time Resolution of ClimateProxy Records from Shallow Fluctuating Lakes. Quaternary Science Reviews 18: 821-837.

Verschuren, D., K.R. Laird, and B.F. Cumming. 2000. Rainfall and Drought in Equatorial East Africa during the Past 1,100 Years. Nature 403: 410-414.

von Höhnel, L. 1892. Zum Rudolph-See Un Stephanie-See. Die Forschungsreise Des Grafen Samuel Teleki in Ost-Aequatorial-Afrika 1887-1888. Vienna: Wilfred Gölder.

-- . 1894a. Discovery of Lakes Rudolf and Stephanie: A Narrative of Count Samuel Teleki's Exploring and Hunting Expeditions in Eastern Equatorial Africa in 1887 and 1888. Vol 2. 1st Editio. London: Longmans, Green, and Co.

-- . 1894b. Discovery of Lakes Rudolf and Stephanie: A Narrative of Count Samuel Teleki's Exploring and Hunting Expeditions in Eastern Equatorial Africa in 1887 and 1888. Vol 1. London: Longmans, Green, and Co.

Wakefield, T., and K.J. Johnston. 1870. Routes of Native Caravans from the Coast to the Interior of Eastern Africa, Chiefly from Information Given by Sadi Bin Ahedi, a Native of a District near Gazi, in Udigo, a Little North of Zanzibar. Journal of the Royal Geographical Society of London 40: 303-339.

Waller, R.D. 1985. Ecology, Migration, and Expansion in East Africa. African Affairs 84, no. 336: 347370.

- - . 1990. Tsetse Fly in Western Narok, Kenya. The Journal of African History 31, no. 1: 81-101.

Wesson, C.B. 1999. Chiefly Power and Food Storage in Southeastern North America. World Archaeology 31: 145-164.

Widgren, M., and N.T. Håkansson. 2007. Labour and Landscapes: The Political Economy of Landesque Capital in Nineteenth Century Tanganyika. Geografiska Annaler Series B, Human Geography 89: 233-248. 
Widgren, M., and J.E.G. Sutton. 2004. Islands of Intensive Agriculture in Eastern Africa. Ed. Mats Widgren and John E. G. Sutton. Oxford: James Currey.

Wolff, C., G.H. Haug, A. Timmerman, J.S.S. Damsté, A. Brauer, D.M. Sigman, M.A. Cane, and D. Verschuren. 2011. Reduced Internannual Rainfall Variability in East Africa During the Last Ice Age. Science 333: 743-747.

Wynne-Jones, S. 2010. Lines of Desire: Power and Materiality Along a Tanzanian Caravan Route. Journal of World Prehistory 23: 219-237.

Zori, D., J. Byock, E. Erlendsson, S. Martin, T. Wake, and K.J. Edwards. 2013. Feasting in Viking Age Iceland: Sustaining a Chiefly Political Economy in a Marginal Environment. Antiquity 87: 150165. 


\section{List of figures/Figure captions}

Figure 1: Map of Lake Baringo and the surrounding area with archaeological sites mentioned in text

Figure 2: Picture of Ilchamus Leabori taken by Harry Johnston in c. 1899 (Reproduced with permission by the (C) Royal Geographical Society (with IBG)

Figure 3: Aerial photograph DOS Aerial Photos Kenya 82D/138/5228 taken by the Department of Overseas Survey in 1950 showing irrigation furrows (seen as lines of denser vegetation) and the location of Ilchamus Leabori (white circle) (Reproduced with permission by the Bodleian Libraries, University of Oxford)

Figure 4: Sketch of farming blocks within the irrigation systems based on ethnographic observations by Nik Petek and Little $(1992,75)$

Figure 5: Imported items associated with the caravan trade recovered during excavations at Ilchamus Lekeper: a) European stoneware (beer or water bottle); b) vial; c) copper covered wire turned into earring; d) bottle base with inscription "T HE"; e) wound glass bead; f) white and blue glass bead

\footnotetext{
${ }^{1}$ We recognize that this was not a universal transformation and that some East African pastoralists, such as the Gada who occupy the border areas between Kenya and Ethiopia, retain age-set based systems of time reckoning of greater temporal depth than those discussed by Anderson (2016) (see e.g. Kasaam 2006). We are grateful to Bilinda Straight for pointing this out.

${ }^{2}$ Oral histories were collected by: a) Nik Petek and assistants Wilson Tiren, Glen Nakure, and Fernandos Kredgie during semi-structured key-informant interviews of elders of the llmeduti age-set and their female counterparts between March and July 2015; and b) David Anderson and his assistants in 1980 during interviews with elders of the Ilnapunye, Ririmpot, and the Ilparemo age-sets. The authors would like to thank David Anderson for sharing his data. Transcripts of the interviews are held by Nik Petek and David Anderson, respectively.

${ }^{3}$ For a similar argument in relation to the Pastoral Neolithic pillar sites of in Turkana, see Marshall, Grillo, and $\operatorname{Arco}(2011)$
} 